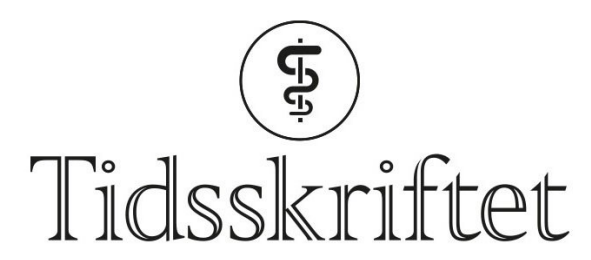

DEN NORSKE LEGEFORENING

\title{
Har et «filleristet spedbarn» alltid vært filleristet?
}

KRONIKK

\section{KNUT WESTER}

E-post: kgwe@helse-bergen.no Knut Wester er spesialist i nevrokirurgi og pensjonert overlege ved Haukeland universitetssjukehus og professor emeritus ved Universitetet i Bergen.

Forfatteren har fylt ut ICMJE-skjemaet og oppgir følgende interessekonflikter: Han har medvirket som medisinsk sakkyndig i rettssaker vedrørende filleristing av spedbarn.

Det er grunn til bekymring om usikkerheten ved diagnostiseringen i filleristingssaker. Jeg etterlyser vitenskapelig holdbar dokumentasjon i disse sakene.

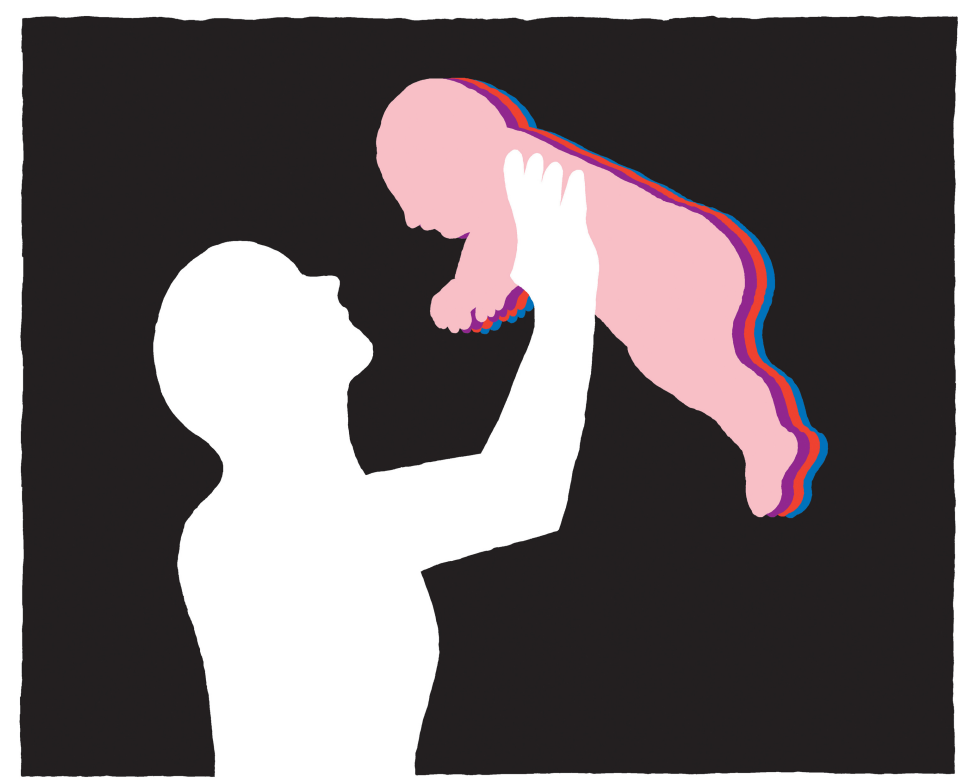

Illustrasjon: Espen Friberg

Fysisk mishandling av spedbarn forekommer, også med hjerneskade til følge. Jeg er imidlertid usikker på om den medisinske dokumentasjonen som sakkyndige i dag vurderer som bevis på filleristing, er av tilstrekkelig vitenskapelig kvalitet til at den kan brukes som juridisk bevis for at denne handlingen faktisk har funnet sted og at det følgelig foreligger «skyld ut over enhver rimelig tvil».

Dette gjelder saker hvor det foreligger mistanke om fysisk mishandling av spedbarn i form av «filleristing» (shaken baby syndrome), og hvor foresatte blir mistenkt for denne kriminelle handlingen. Nomenklaturen på området er under stadig endring; også begrep som "påført hodeskade» (abusive head trauma) brukes om tilstanden. 
Som pensjonist har jeg blitt involvert i noen slike rettssaker som sakkyndig, både i straffesaker og barnevernssaker. Det forelå ingen sikre ytre tegn på skade i noen av sakene, men sakkyndige hadde konkludert med at filleristing var årsak til spedbarnets tilstand selv om en ledende ekspert sier at risting alene ikke er tilstrekkelig, det kreves slag mot hodet for å få slike skader (1).

Etter å ha satt meg bedre inn i den relevante litteraturen, spør jeg: Er det tilstrekkelig beviskraft i den kombinasjonen av medisinske funn som inngår i den såkalte «triaden» og som av sakkyndige anses som dokumentasjon på at filleristing har funnet sted?

\section{Triaden}

Triaden består av tre medisinske funn: subduralt hematom, utbredte øyebunnsblødninger og encefalopati. Min erfaring, og også vist i litteraturen $(2,3)$, er at encefalopati ikke lenger er nødvendig for diagnosen «shaken baby». Kombinasjonen av subduralt hematom og øyebunnsblødninger synes tilstrekkelig. Disse funnene brukes nå nærmest som sikker dokumentasjon på at filleristing må ha funnet sted, selv om ingen har sett selve handlingen.

Om triaden skal kunne tillegges rettslig beviskraft, må de publikasjoner som hevdes å vise en sikker årsakssammenheng mellom disse funnene og risting være av så god vitenskapelig standard at det ikke kan reises tvil om beviskraften. Jeg har hittil ikke vært i stand til å finne artikler av slik kvalitet.

Så godt som ingen filleristingsartikler jeg har lest baserer seg på vitneobservasjoner eller troverdig tilståelse i nær tidsrelasjon til den påståtte kriminelle handlingen. I stedet vises det ofte til multidisiplinære konsensusavgjørelser, som for eksempel «evaluated by the hospital's child abuse evaluation team» (4). I tillegg til å bygge avgjørelsen på triaden, vises det til manglende troverdighet hos den som var alene med spedbarnet da det ble akutt dårlig. Dersom vedkommende ikke kan presentere en plausibel traumesykehistorie som kan forklare funnene, er dét ifølge én algoritme tilstrekkelig til å styrke mistanken (5). Ifølge en annen algoritme gjør det filleristingsdiagnosen «høyst sannsynlig» (6). Disse algoritmene baserer seg på tidligere litteratur hvor grunnlaget for diagnosekriteriene ikke synes å ha blitt vitenskapelig etterprøvd. Det er sannsynlig at diagnostisering på basis av algoritmene vil prege også fremtidige artikler, som derved legges til eksisterende litteratur som ytterligere bevis på filleristing - en sirkelbevisføring.

Problemet med triaden er at disse medisinske funnene også kan finnes ved andre tilstander. I en offentlig svensk utredning påpekes det at nesten all dokumentasjon baserer seg på sirkelbevisføring. Etter en omfattende litteraturgjennomgang konkluderer den med at det er begrenset kunnskapsgrunnlag (low quality evidence) for at triaden kan knyttes til traumatisk risting, og at det er utilstrekkelig kunnskapsgrunnlag (very low quality evidence) for triadens diagnostiske sikkerhet ved traumatisk risting (7).

Den svenske utredningen, som konkluderer så dramatisk vedrørende triadens, eller dens komponenters, manglende vitenskapelighet, besto av fagpersoner innen pediatri, rettsmedisin, nevroradiologi, medisinsk metodelære og medisinsk etikk. Tre av de medisinske fakultetene i Sverige var representert. Deres konklusjoner har med få unntak ført til at svenske rettsmedisinere ikke lenger vektlegger triaden ved mistenkt risting (Ingemar Thiblin, leder i Svensk Rättsmedicinsk Förening, personlig meddelelse).

Tilhengerne av triadens betydning som bevis henviser til to franske studier fra $2010(3,8)$. Ingen av disse viser til funn hos spedbarn hvor ristingen er observert, den er bare tilstått -men først uker eller måneder etterpå - i politi- eller dommeravhør. Tilståelser fremkommet under slike omstendigheter er beheftet med atskillig usikkerhet (9).

\section{Benign ekstern hydrocephalus}

Triadens enkeltkomponenter kan også finnes ved andre tilstander. Benign ekstern hydrocephalus er en slik tilstand, som skyldes et misforhold mellom produksjon og 
eliminasjon av hjernevæske. Ved benign ekstern hydrocephalus hoper hjernevæsken seg opp mellom hjernen og skallens innside, det intrakraniale trykket øker, det ekstracerebrale væskerommet utvides og hodeomkretsen vokser. Brovenene, som går gjennom dette væskerommet fra hjernebarken til kraniets innside, blir satt på strekk og kan begynne å småblø og forårsake subdurale blodansamlinger. Disse er vanligvis ikke akutte, men fremstår mer som kroniske blodansamlinger av forskjellig alder. Ferske blodprodukter, som ved et akutt hematom, utgjør vanligvis en svært liten andel av det totale væskevolum ved subdurale blodansamlinger forårsaket av benign ekstern hydrocephalus.

Subdurale hematomer forekommer altså som spontan komplikasjon til benign ekstern hydrocephalus (10, 11). Dette kan utgjøre en diagnostisk fallgruve med henblikk på filleristingsdiagnosen (10). Følgelig kan ikke subduralt hematom være patognomonisk for filleristing.

Epilepsi med bevisstløshet og kramper kan være et dramatisk debutsymptom ved benign ekstern hydrocephalus $(12,13)$. En rimelig reaksjon hos foreldre som opplever et plutselig anfall med bevisstløshet og respirasjonsstans, vil være å forsøke å riste liv i barnet - en handling som kan misoppfattes og styrke mistanken ytterligere.

Jeg har sammen med medarbeidere nylig publisert en studie som viser at det årlig fødes omtrent 25 barn med benign ekstern hydrocephalus i Norge (14). De er født med normal hodeomkrets, men denne vokser for raskt de første månedene etter fødselen. Det er også en uttalt gutteovervekt ( $86 \%$ ) blant disse barna. En tilsvarende alders- og kjønnsfordeling finnes i de fleste større filleristingsartikler, for eksempel Adamsbaum, Hobbs og Vinchon, som til sammen hadde en gutteovervekt på $70 \%(3,8,15)$ og en snittalder på fire måneder. Kan den epidemiologiske likheten mellom benign ekstern hydrocephalus og filleristing med henblikk på alder og kjønn skyldes at benign ekstern hydrocephalus med subduralt hematom som komplikasjon blir feildiagnostisert som filleristing?

Filleristing og benign ekstern hydrocephalus kan ifølge litteraturen begge gi subdurale hematomer. Da skulle man vente at det var forskjell på det radiologiske bildet hos de to. Som oftest blir tidspunktet for en antatt risting fastsatt til umiddelbart før barnet blir akutt dårlig, og den som da var alene med barnet er den som blir mistenkt. Hvis hematomet er forårsaket av en akutt handling, skulle man vente et akutt utseende hematom med hvitt, koagulert blod (ved CT), og ikke et kronisk hematom eller bare blodtilblandet væske, slik man ofte ser i slike saker. Likeledes burde man ved et akutt hematom vente å finne kompresjon av ventrikler og subduralrommet samt en overskytning av hjernens midtlinje til motsatt side dersom blødningen er ensidig.

På den annen side, dersom den subdurale blodansamlingen er en komplikasjon til benign ekstern hydrocephalus, og skyldes gradvis blodutsiving i et allerede utvidet ekstracerebralrom, burde det subdurale hematomet ha utseende som nettopp det: et kronisk subduralt hemtom, kanskje med enkelte mindre akutt utseende koagler.

Er det da en tydelig radiologisk forskjell mellom CT- og MR-bilder som presenteres som henholdsvis benign ekstern hydrocephalus og filleristing? Til dels er det det, men etter min vurdering bare i liten grad. Jeg fant 40 artikler publisert de siste ti årene med illustrasjoner som skal vise eksempler på filleristing. I disse artiklene var det til sammen 68 MR-eller CTbilder som ifølge forfatterne viste eksempler på filleristing uten tegn til ytre vold. Et stort flertall av disse ( $78 \%$ ) hadde radiologiske karakteristika som passer bedre med benign ekstern hydrocephalus enn med en hodeskade påført ved akutt vold (16). Bare $22 \%$ var mest forenlig med et traumatisk betinget akutt subduralt hematom. Denne radiologiske likheten mellom angivelig filleristing og benign ekstern hydrocephalus fremgår også av illustrasjoner som angis å fremstille benign ekstern hydrocephalus $(11,16)$ og filleristing $(8$, 17). Disse bildene er for meg skremmende like.

Hvorfor disse spedbarna også får utbredte retinale blødninger, er ikke fastslått med sikkerhet, men høyt intrakranialt trykk kan medføre slike blødninger - såkalt Tersons syndrom (18). Forhøyet intrakranialt trykk formidles via væskeskjeden rundt 
synsnerven, som hos spedbarn er meget kort, til øyebunnen, noe som gir blødninger. Heller ikke utbredte retinale blødninger kan anses som ensbetydende med filleristing $(10,19,20)$.

\section{Startet forskningsprosjekt}

Jeg er bekymret over usikkerheten ved diagnostiseringen av filleristing i straffe- og barnevernssaker. Slik jeg har tolket kliniske funn og bilder i de saker jeg har vært involvert i, blant annet med raskt $ø$ kende hodeomkrets forut for den antatte ristingen, synes ekstern hydrocephalus ofte å være en mer sannsynlig diagnose enn at barnet faktisk har vært filleristet.

Vi har startet et forskningsprosjekt, hvor hensikten er å gå igjennom det medisinske grunnlaget for dommer i slike straffesaker ved norske domstoler. Prosjektet har fått alle nødvendige godkjenninger fra følgende instanser: Den nasjonale forskningsetiske komité for medisin og helsefag (NEM), Datatilsynet og Riksadvokaten. Med i forskningsgruppen er jusprofessorene Aslak Syse og Ulf Stridbeck ved Universitetet i Oslo, én nevroradiolog og én barnenevrokirurg, de to siste fra land utenfor Norge.

Dette angår rettssikkerheten i saker som kan medføre langvarige fengselsstraffer eller at barn blir varig separert fra foreldrene. Jeg etterlyser vitenskapelig holdbar dokumentasjon for at de kriterier som nå legges til grunn, virkelig kan brukes som juridiske bevis for «skyld ut over enhver rimelig tvil» i filleristingssaker. I slike saker er dommerne helt avhengig av medisinsk ekspertise. Dersom de råd sakkyndige gir i retten er basert på svakt vitenskapelig grunnlag, kan det få alvorlige konsekvenser.

\section{LITTERATUR:}

1. Duhaime AC, Gennarelli TA, Thibault LE et al. The shaken baby syndrome. A clinical, pathological, and biomechanical study. J Neurosurg 1987; 66: 409 - 15. [PubMed][CrossRef]

2. Hansen JB, Frazier T, Moffatt M et al. Evaluations for abuse in young children with subdural hemorrhages: findings based on symptom severity and benign enlargement of the subarachnoid spaces. J Neurosurg Pediatr 2018; 21:31 - 7. [PubMed][CrossRef]

3. Vinchon M, de Foort-Dhellemmes S, Desurmont M et al. Confessed abuse versus witnessed accidents in infants: comparison of clinical, radiological, and ophthalmological data in corroborated cases. Childs Nerv Syst 2010; 26: 637-45. [PubMed][CrossRef]

4. Binenbaum G, Rogers DL, Christian CW, Forbes BJ et al. Odds of abuse associated with retinal hemorrhages in children suspected of child abuse. J AAPOS 2009; 13: 268 - 72. [PubMed][CrossRef]

5. Duhaime AC, Alario AJ, Lewander WJ et al. Head injury in very young children: mechanisms, injury types, and ophthalmologic findings in 100 hospitalized patients younger than 2 years of age. Pediatrics 1992; 90: 179 - 85. [PubMed]

6. Reece RM. What are we trying to measure? The problems of case ascertainment. Am J Prev Med 2008; 34 (suppl): S116 - 9. [PubMed][CrossRef]

7. Traumatic shaking - The role of the triad in medical investigations of suspected traumatic shaking. A systematic review. SBU assesment 255E/2016. Stockholm: Swedish Agency for Health Technology Assessment and Assessment of Social Services (SBU), 2016.

https://www.sbu.se/contentassets/ogcc34e7666340a59137ba55d6c55bc9/traumatic_shaking_2016.pdf (27.8.2018).

8. Adamsbaum C, Grabar S, Mejean N et al. Abusive head trauma: judicial admissions highlight violent and repetitive shaking. Pediatrics 2010; 126: 546 - 55. [PubMed][CrossRef]

9. Gudjonsson G. Memory distrust syndrome, confabulation and false confession. Cortex 2017; 87: 156 65. [PubMed][CrossRef]

10. Piatt JH. A pitfall in the diagnosis of child abuse: external hydrocephalus, subdural hematoma, and retinal hemorrhages. Neurosurg Focus 1999; 7: e4. [PubMed][CrossRef] 
11. Vinchon M. Subdural hematoma in infants: can it occur spontaneously? Data from a prospective series and critical review of the literature by Vinchon et al. Childs Nerv Syst 2010; $26: 1485$.

[PubMed][CrossRef]

12. Ghosh PS, Ghosh D. Subdural hematoma in infants without accidental or nonaccidental injury: benign external hydrocephalus, a risk factor. Clin Pediatr (Phila) 2011; 50: 897 - 903.

[PubMed][CrossRef]

13. Hellbusch LC. Benign extracerebral fluid collections in infancy: clinical presentation and long-term follow-up. J Neurosurg 2007; 107 (suppl): 119 - 25. [PubMed]

14. Wiig US, Zahl SM, Egge A et al. Epidemiology of benign external hydrocephalus in Norway -a population-based study. Pediatr Neurol 2017; 73:36 - 41. [PubMed][CrossRef]

15. Hobbs C, Childs AM, Wynne J et al. Subdural haematoma and effusion in infancy: an epidemiological study. Arch Dis Child 2005; 90: 952 - 5. [PubMed][CrossRef]

16. Maytal J, Alvarez LA, Elkin CM et al. External hydrocephalus: radiologic spectrum and differentiation from cerebral atrophy. AJR Am J Roentgenol 1987; 148: 1223 - 30. [PubMed][CrossRef]

17. Wittschieber D, Karger B, Niederstadt T et al. Subdural hygromas in abusive head trauma: pathogenesis, diagnosis, and forensic implications. AJNR Am J Neuroradiol 2015; 36: 432 - 9. [PubMed][CrossRef]

18. De Terson A. L'hemorrhagie dans le corps vitre au cours de l'hemorrhagie cerebrale. Clin Ophthalmol 1900; 6:309-12.

19. Barnes PD, Galaznik J, Gardner H et al. Infant acute life-threatening event-dysphagic choking versus nonaccidental injury. Semin Pediatr Neurol 2010; 17: 7 - 11. [PubMed][CrossRef]

20. Scheller J. Infantile retinal haemorrhages in the absence of brain and bodily injury. Acta Paediatr 2017; 106: 1902 - 4. [PubMed][CrossRef]

Publisert: 27. september 2018. Tidsskr Nor Legeforen. DOI: 10.4045/tidsskr.18.0583

Mottatt 19.7.2018, første revisjon innsendt 17.8.2018, godkjent 27.8.2018.

(C) Tidsskrift for Den norske legeforening 2020. Lastet ned fra tidsskriftet.no 